\title{
Miranda
}

Revue pluridisciplinaire du monde anglophone /

Multidisciplinary peer-reviewed journal on the English-

speaking world

13 | 2016

Thomas Spence and his Legacy: Bicentennial

Perspectives

\section{Radical legacy or intellectual indelicacy? Ebenezer Howard's use of "the most admirable project of Thomas Spence" in the Garden City concept}

Jean-Yves Tizot

\section{OpenEdition}

\section{Journals}

Electronic version

URL: http://journals.openedition.org/miranda/9173

DOI: 10.4000/miranda.9173

ISSN: 2108-6559

Publisher

Université Toulouse - Jean Jaurès

\section{Electronic reference}

Jean-Yves Tizot, "Radical legacy or intellectual indelicacy? Ebenezer Howard's use of "the most admirable project of Thomas Spence" in the Garden City concept", Miranda [Online], 13 | 2016, Online since 17 November 2016, connection on 16 February 2021. URL: http://journals.openedition.org/ miranda/9173 ; DOI: https://doi.org/10.4000/miranda.9173

This text was automatically generated on 16 February 2021.

\section{c) (1)}

Miranda is licensed under a Creative Commons Attribution-NonCommercial-NoDerivatives 4.0 International License. 


\title{
Radical legacy or intellectual indelicacy? Ebenezer Howard's use of "the most admirable project of Thomas Spence" in the Garden City concept
}

\author{
Jean-Yves Tizot
}

In a famous 1958 article on Ricardo's theory of value, the American economist George J. Stigler, commenting briefly on the importance of the fame and reputation of ideas in their historical transmission, remarked on the difficulty for scholars of ever being able to give a second chance to ideas that have been initially misjudged:

The basic reason Ricardo's theory is often misinterpreted is that it was often misinterpreted in the past. If a theory once acquires an established meaning, each generation of economists bequeaths this meaning to the next, and it is almost impossible for a famous theory to get a fresh hearing. Perhaps one hearing is all a theory is entitled to, but one may plead that Ricardo deserves at least a rehearinghis theory is relatively more widely misunderstood today than it was in his lifetime. One can build a strong case that the modern economist need not be acquainted with Ricardo's work, but there is no case for his being acquainted with an imposter. (Stigler 367)

With a few changes-"Spence" for "Ricardo", "historian" for "economist", "idea" instead of "theory", for example-very much the same observation might apply to Spence and the fate of his "Land Plan" in the treatment of most of his successive interpreters and commentators. Spence's idea of a self-governed, self-financing, landowning, democratic parish corporation has often been regrettably misunderstood and at times perhaps deliberately misinterpreted. Hence, perhaps, his present status as an unknown celebrity of British revolutionary radicalism.

3 Various authors are to blame for conveying a distorted image of what the Land Plan really was, and Spence himself, because of the confusion resulting from his numerous 
expositions of his central political concept, could be the first of them. Orthodox Marxists, because they wanted to present Spence as one of their glorious ancestors, and claimed that his plan was a primitive recipe for centralised "land nationalisation", are considered by some as the main culprits. Ebenezer Howard, the author of Garden Cities of To-morrow ${ }^{1}$, could be another.

4 In one of the final chapters of his celebrated essay on the Garden City idea, Ebenezer Howard refers to Spence's "Land Plan" in the very positive terms mentioned in the above subtitle. The chapter is devoted to elucidating the origins and components of his Garden City project, and in it Howard does in fact more than just refer to Spence's main political idea. He actually explains in the first paragraphs that, having previously examined a number of other ideas, he combined them together with a view to finding the optimal formula for his "scheme":

It is my present purpose to show that though the scheme taken as a whole is a new one, and is, perhaps, entitled to some consideration on that account, its chief claim upon the attention of the public lies in the fact that it combines the important features of several schemes which have been advocated at various times, and so combines them as to secure the best results of each, without the dangers and difficulties which sometimes, even in the minds of their authors, were clearly and distinctly seen.

5 Readers will learn later in the chapter that this selection is carried out "so that the most admirable project of Thomas Spence can be put into practice". This is but one of several obvious clues as to the centrality of Spence's Land Plan in Howard's urban reform programme. But Howard never actually explains in his own words what he means by Spence's "admirable project", leaving readers guess what it might be from the quotation he supplies. Tellingly, the chapter in question is entitled "A Unique Combination of Proposals": only a few pages long, it contains many extensive quotes from various authors whose ideas Howard "borrowed" and re-used for the purpose of constructing his own Garden City concept. Among them is what seems to be a passage from Spence but which is only referenced in brackets as "From a lecture read at the Philosophical Society in Newcastle, on the $8^{\text {th }}$ November 1775 , for printing which the Society did the author the honour to expel him" at the end of the extract.

6 Spence scholars will undoubtedly recognise this and will be able to situate the origin of the extract. ${ }^{2}$ But would anyone else? How many among the readers of Howard, for more than a century now, have been able to judge whether the reference to Spence is both authentic and appropriate within the context of the Garden City idea? This case of intellectual borrowing and recycling is an illustration of a more general problem which historians of ideas have to confront as a matter of course in their discipline, the problem of the interpretation and instrumentalisation of ideas.

7 As they are disseminated throughout the literate society of their day, and eventually passed on to the following generations, one doubt can never be wholly lifted: before starting this historical journey, how much of any original idea, as and when it was first expressed, was actually correctly understood and interpreted by its audience? This in turn gives occasion to a number of equally serious questions, such as: was the idea expressed clearly enough? Were the audience well-enough equipped to really grasp its finer points? If the answers to some or all of these questions are in the negative, then how many distortions were thus successively inflicted on the concept in the course of its transmission through time? And, were any of these distortions voluntary, or did 
they happen through circumstance, error or incompetence? There are more, which we will examine in due course.

The aforementioned doubts and questions about the genealogy of ideas all plead in favour of returning to the originals in question here-both Spence's and Howard's-with a view to tracing Howard's borrowing back to its native context and meaning. With such precautions in mind, we will look at Spence's contribution to the Garden City project from the other end of the intellectual transmission chain-i.e. as it appears in Howard's text-to question the use that Howard made, for his own purposes, of the democratic land-owning parish idea, or "Land Plan". In particular, we will envisage the possibility that in borrowing Spence's idea, Howard might have exported several functions from a larger system of interconnected ideas (or "concept") to try and import them into a substantially different, possibly also divergent set of ideas and intentions. Whether that operation has been a success, intellectually, morally, and otherwise, is another question we will ask and try to answer.

9 This capital influence, or perhaps importation, is not only mostly ignored or little commented on by Howard and Garden City specialists. Remarkably, it is also one that jars which the general tonality and content of Howard's message-the latter fact perhaps a reason for the former. Howard's intellectual horizon is one of "peaceful reform" and of functional improvement of the operating environment (both human and spatial) of late-19 $9^{\text {th }}$ century capitalism. The ultimate goal in the Garden City project was globally to sanitise, harmonise and pacify social relations in the industrial city and to rationalise the use of the countryside for the benefit of a renewed urbanism. Spence's own legacy, on the other hand, is rather one of revolt and rebellion against landowning interests and the domination of "usurpers and tyrants" over the lives of common people. As a Jacobin radical, his intentions were clearly revolutionary, and for expressing and disseminating them he was imprisoned repeatedly, sometimes without trial. The two thinkers seem to have rather diverging perspectives, and that makes the question of how Howard managed to recycle Spence's radical Land Plan idea all the more urgent to examine.

We will first briefly explain the content of Spence's "Land Plan", and clarify the general meaning of the Garden City idea such as Howard formulated it himself (like Spence's Land Plan, the Garden City scheme itself is another example of an idea that has often been partly misinterpreted and partially misrepresented). Then the value and importance of Thomas Spence's free land-owning parish idea for the Garden City concept will be examined, in order to try and evaluate the adequacy and consistency of this borrowing with Spence's original idea, as well as with Howard's own goals and objectives. Lastly, an attempt will be made to assess the consequences of Howard's reinterpretation, and of accommodating it to the multifaceted and perhaps slightly incoherent vision that was his Garden City, for the contemporary understanding of Spence's Land Plan, and perhaps of Spence's thought in general.

\section{Some essential features of Spence's Land Plan}

11 A brief overview of the fundamental elements of Spence's "big idea" will provide a basis for comparing and contrasting it with Howard's one and only town and country reform idea. It will focus on the features that might best allow for a fair assessment of the 
influence of Spence's "admirable project" on Howard, or rather the use that the latter made of the former's idea.

Contrary to what many of Spence's commentators-including some of his followersseem to have understood, Spence was consistently favourable to a system of local, communal land ownership, and always hostile to central government ownership and control of the land. ${ }^{3}$ Spence believed that mere political empowerment-"representation", "democracy"-would never be enough to protect the poor from the oppression of the rich, in particular the rent-extracting landed classes. In this he differs from other early radicals-and indeed from the later "mainstream" radical demand for political reform only (or mainly), and arguably preceded the formation of an articulated British socialist agenda. ${ }^{4}$

Private property in land, according to Spence, had originally been established through force, theft or fraud, and its repossession by the people therefore seemed to him a very legitimate proposition. To do so, Spence argued, the inhabitants of every parish could and should form a parish corporation or municipality and constitute themselves, through the corporation, the collective owners of all the land within the parish boundaries. This would give effective power to the people, instead of it being held by a landowning minority or those in positions of local executive authority.

In Spence's plan, if this revolutionary reversal in land property were to spread throughout the entire country-which was the distant horizon of his proposition, then the land would be owned by the numerous parochial corporations, not the state. "The local inhabitants, not the central government, would own and control, not merely administer, the land" (Dickinson 1982). As Spence saw it, this would be the basis for real democracy and popular empowerment.

As we will see, none of these aspects were of any direct import in Howard's formulation of his Garden City concept, apart perhaps from a very pragmatic but reversible aversion to central government intervention (action on a national scale should wait until after the success of the first Garden City-type settlements). What attracted Howard's interest however, was the social and economic model of the Land Plan.

The revenue of incorporated parishes would consist for Spence only in rent paid to parishes by tenants who would exploit the land, which would be leased out to the highest bidders, for a profit, under a regime of "periodic tenancy". The local corporation and the parishioners under its authority would not be allowed to work their own parish land, in order to avoid the problems of corruption and conflicts of interests between the economic and political spheres. For the same reasons, the tenants would never be allowed to own the land they exploited, and therefore (like the corporations themselves), would not be able to sell the land and thus alienate the collective property of the parish population. These principles were in fact to be extended to the exploitation of all other resources within the parish boundaries, and could therefore include fishing, forestry, mining and as many other activities as the natural assets and environment of the parish territory would allow.

Based on the total of the rents paid into the parish treasury, Spence thought, public infrastructure and equipment needs arising within the parish territory could be financed concurrently with a contribution to national administration, while leaving perhaps one half or up to two thirds of the rent monies to be distributed in equal shares between the children, women and men of the parish at regular intervals. A 
range of public services (baths, libraries, schools and more), along with pubic relief to those whose condition or circumstances did not allow them to derive subsistence from work or employment, would also be funded, according to Spence's plan, out of the remainder of the parochial rent. Parish inhabitants would globally benefit from such a system through the eradication of destitution, the absence of taxes and the payment to all of an equal share of the unspent parish rent funds.

The guiding principles and foundations of the Land Plan were thus: a specific regime of collective ownership of the parish resources in which all individuals inhabitants have the same right to ownership of the exploitable resources through the parish corporation; the indirect exploitation of resources by the leasing of these resources to outsiders; the funding of the parish treasury by rents paid by the highest bidders for the right to exploit resources; and equality of entitlement to parish services and solidarity within the local community, the absence of taxes on local parishioners.

\section{Howard's Garden City concept}

19 The richly detailed plans proposed by Howard to illustrate his literal descriptions of his projected "Town-Country", or "Rurisville", are famous among planners, planning students and scholars, and well known to anyone with an interest in planning history, theory or practice. ${ }^{6}$ These aspects of Howard's vision-the planning and architectural dimensions-are certainly the best known and have attracted most of the attention accorded to the Garden City. It is worth noting here that, like the analytical part of Howard's concept, the spatial elements are themselves a collection and combination of previously existing plans and ideas. Here too, Howard is mainly a compiler.

However, although the Garden City scheme is mostly remembered for its spatial planning dimension, there has been a growing realisation over the last decades of the $20^{\text {th }}$ century that the main interest of his plan probably lies elsewhere. The global interpretation of Howard's work in the decades after his death (in 1928) consistently lay the emphasis on spatial planning aspects, and underestimated or even plainly neglected the alternative social and economic vision on which Howard based his whole scheme, Colin Ward noted in 1992 (24):

The social reformism of the garden city idea was quickly converted into an environmental reformism which was in turn technicalised and dissembled to form part of the emerging professional practice of town planning.

21 This was already true in the 1930s when an embryonic national planning system appeared, but especially in the post-World War II context of central dirigiste policies of reconstruction and subsequent urban expansion. Foldvary $(1994,101)$ has also argued convincingly that the focus of Howard reformism was not where most commentators usually situated it:

Howard's primary goal was the reform of economic arrangements rather than the mere architectural innovation [...] His emphasis was on the city rather than the garden [...] with a view towards decentralizing government. related aspects of the Garden City project were far from central to Howard's vision", and remarked that the essential element in Howard's plan is in fact the "governance model" he proposed to establish and operate the Garden City. 

as one of two neglected precursors of a current liberal-libertarian agenda in land-use planning which they seem to explore and, in fine, to promote. One of these is the anarcho-capitalist, or "minarchist" (from "minimal statism") Spencer Heath, who has also been variously described as a libertarian or free-trade activist. These descriptions can serve as an indication of the ideological colouring of Brunetta and Moroni's approach. The other author they consider as a forbearer of libertarian "contractual communities" is Howard.

Taking stock of the aforementioned renewed or "revisionist" views on the Garden City project, they consider Howard, in this perspective, as a precursor to their own (and others') contributions on the existence, desirability and feasibility of what they term "contractual communities". By this they mean privately owned, for-profit (mainly) largescale real estate ventures hosting a variety of collective uses, of which the better known examples are the proprietary community (business parks, residential or mixed-use estates under a single private owner) and the homeowners association. Private developments and towns, on the model of Disney's famous Celebration in Florida for example, are for them one of the ways in which private real estate capitalism can evade the constraints and regulations of public administration. Their little book is significantly entitled Contractual Communities in the Self-Organising City, while the subtitle Freedom, Creativity, Subsidiarity could easily be recycled as the libertarian motto of some tax-abolition society.

However clearly ideological their investigation of Howard's concept might be, Brunetta and Moroni have a point: Howard did envisage the Garden City project as a private, and, if successful, profitable venture, especially-quite logically-for those whose invest the most: the project is heavily dependent on industrial and commercial capital investment, and on the increase in land-value, and therefore of land rent revenues resulting from their success. They describe the concept as follow:

The fulcrum of Howard's proposal (1898) is a particular form of organization of life in common. Garden City is original not so much for the presence of the green areas as, above all, for the organisational model that was proposed. Howard (1898) imagined that a group of people would buy uninhabited farm areas in order to found a settlement characterised as particular organizations, namely Garden Cities. Howard spoke explicitly of a "voluntary organisation" [...]. He hypothesised that the necessary areas $(6,000$ acres $)$ be bought through a special financial mechanism that involved a financial exposure to debt. This debt was something to be reduced progressively over time. The areas were to be entrusted to four "trustees", who held the property "on behalf" of the citizens [...]. Therefore Howard's idea did not consider the state (public) ownership of land; Howard's theoretical proposal, as presented in his book, does not call for the nationalisation of the land, not even through gradual steps (despite the fact that many authors keep asserting this is so). Land was to be owned in common by the citizens; this was just a particular form of private property (67).

The social community thus founded would depend on what Howard called the raterent, against the payment of which residents-rather than "citizens"-could freely use their lodgings, allotments, etc., and the businesses their shops, warehouses and so on, of which they would be, in effect, the tenants rather than the owners. The managing company would be their landlord. Howard explains in Chapter 2 of Garden Cities of Tomorrow that once the initial debt had been cleared, the "rate-rent" payments would go towards financing collective amenities and facilities, and eventually even welfare 
services such as old-age pensions, insurance policies against loss of income due to sickness or incapacity, and such like. Howard thought that the Garden City collective could manage a number of services the way municipalities did, but that the private sector could also step in to replace municipal services if and when they were found to be more efficient or cost-efficient than the latter. Among other advantages, the Garden City could thus afford itself the free choice of "service providers" thanks to its own rate-rent self-financing system.

Howard wrote that the organisational form of the "town estate" would be structured like a "large and well-appointed business", and indeed the management or, more properly, governance of the Garden City is modelled very closely on the structure of a large private company, complete with board of directors-which here is called "Board of management"-and shareholders-the rent-paying inhabitants and businesses, or tenants. The chairmen and vice-chairmen or the Board of management together form the "Central Council":

In this council (or its nominees) are vested the rights and powers of the community as sole landlord of Garden City. Into its treasury are paid (after provision has been made for landlord's rent and sinking fund) all rate-rents received from its tenants, as well as the profits derived from its various municipal undertakings, and these, we have seen, are amply sufficient to discharge all public burdens without any resort to the expedient of compulsory rates. The powers possessed by the Central Council are, it may be noticed in passing, more ample than those possessed by other municipal bodies, for whilst most of these enjoy only such powers as are expressly conferred on them by Acts of Parliament, the Central Council of Garden City exercises on behalf of the people those wider rights, powers and privileges which are enjoyed by landlords under the common law. The private owner of land can do with his land and with the revenue he derives from it what he pleases so long as he is not a nuisance to his neighbour; while, on the other hand, public bodies which acquire land or obtain power to levy rates by Acts of Parliament, can only use that land or spend those rates for such purposes as are expressly prescribed by those Acts. But Garden City is in a greatly superior position, for, by stepping as a quasi public body into the rights of a private landlord, it becomes at once clothed with far larger powers for carrying out the will of the people than are possessed by other local bodies, and thus solves to a large extent the problem of local self-government (71). ${ }^{7}$

In Chapter 6 of Garden Cities of To-morrow, Howard is very fastidious in his description of the administrative structure of his board of management, which apart from the Central Council, is made up of numerous "Departments", arranged in three "groups" (Public Control, Engineering, Social Purposes), each of which is divided into remit-specific subgroups-these are the departments themselves. The "Public control" group, for example is subdivided into the following departments (each being responsible for the corresponding mission): Finance (receives the "rent-rates"), Assessment (determines "rent-rates" levels), Law (draw up land use contracts and general conditions) and Inspection (checks that rights and duties of both tenants and Garden City as a corporate body are respected). And so on with the rest of the departments. Clearly, the organisation of Garden City governance is directly business-inspired and modelled on the private enterprise management structure. In the words of Brunetta and Moroni (65):

Howard imagined that the organisational form of Garden City would be structured like a "large and well-appointed business". In fact, Garden City is not a public municipality but a private voluntary organisation. 
This entire organisation, however, is concerned with the internal functions of the Garden City as a human settlement, or-with the obvious reservations that apply in this case-"municipality". Another powerful player in the Garden City game, according to Howard's own rule book, was the limited-dividend company, which was accountable to investors alone. Whether it is the "voluntary sector" aspect or the for-profit intention which must actually dominate in the initial model is not clear, and Howard himself does not seem to have caught on the potential for conflict between the two (Hall and Ward 1998, 29). In the story of Letchworth and Welwyn, the first two "Garden Cities" that came into being at the beginning of the $20^{\text {th }}$ century, it was clearly the capitalistic venture that ruled over the "co-operative commonwealth", not least because the directors of the latter were also the board of the former. But that is another story. What is essential here is that at the core of the Garden City's social and economic system lies a form of local elite governance, and not of "local government" according to the law of the land. Howard consciously chose this landowning and entrepreneurial model to by-pass the constraints and regulations of public local authorities and, in his own words, to solve "the problem of local self-government". He clearly considered that the fact that the rule of law in local government matters did not fully apply to the governing body of the Garden City was not a problem, but rather that it was the elegant solution he had found to "carry out the will of the people".

In fact Howard deliberately chose this model of organisation by opposition to the socialist projects or utopias of his time, where nationalisation and the collective ownership of the means of subsistence or production were the main pillars of the social system. Howard justified this by considerations on human nature, and deemed the socialist positions contrary to two essential elements of the human mind:

First, the self-seeking side of man - his too frequent desire to produce, with a view to possessing for his own personal use and enjoyment; and, secondly, his love of independence and of initiative, his personal ambition, and his consequent unwillingness to put himself under the guidance of others for the whole of his working day, with little opportunity of striking out some independent line of action, or of taking a leading part in the creation of new forms of enterprise. (97)

Howard goes on to criticize the failed socialist settlements of Robert Owen (Topolomanbo in Mexico) and William Lane (New Australia and Cosme, both in Paraguay) to illustrate his position that individuals need "opportunities for personal effort" to feel a sense of fulfillment-as if the inhabitants of such colonies had lacked such opportunities at the time. Admittedly, Howard was again not totally original in holding such beliefs, since this disincarnated and classless vision of "the individual" and the "needs of the individual" was (and still is) one of the cornerstones of liberal discourse. And on the other hand, the "self-seeking side of man", the "personal ambition" and the other expressions in the above quotation are all phrases that are strikingly expressive of the entrepreneurial mentality which Howard seems intent on defending and promoting.

Brunetta and Moroni conclude their section on this question of governance with a short but very significant assessment of Howard's general ideological and practical disposition:

In conclusion, Howard differs from many of his contemporaries who seemed to propose solutions that were alternatives to the development of the new industrial era and the market. Howard, instead, tried to insert his project inside the industrial era and the market system, rather than outside or in contrast with it (22). 
ard planned to change the reality of industrial towns and of the depressed countryside and to gradually abolish the evils of urban civilisation by using the very mechanisms of capitalist development that had caused these problems in the first place, and to do so by relying primarily on the main spring that propelled the whole system further into the chaos of profit and poverty that was the British urban system and society in general: market individualism. No reformer ever embraced a truer reformist programme. But, as Brunetta and Moroni aptly point out, the type of reform that Howard proposed was more of the liberal kind than of radical or revolutionary inspiration. to reconcile with market capitalism and economic liberalism. Apart perhaps from Kropotkin's anarchism, Spence's Land Plan seems to be the one idea that sits most uncomfortably with the Garden City's general ideological and political meaning such as we have characterised it, as we will presently try to show.

\section{Spence's Land Plan: influence or borrowing?}

Howard claimed rightly that his own contribution contained nothing original and was only the combination of three pre-existing ideas, among which Spence's Land Plan. He very openly admitted to borrowing and using Spence's central concept to suit his own purpose. In Chapter 10 of his famous Garden City treaty of 1898, To-morrow! A peaceful Path to Real Reform (renamed Garden Cities of To-morrow in 1902), Howard mentions "the most admirable project of Thomas Spence" very explicitly as one of the three major inspirations for his own concept:

Shortly stated, my scheme is a combination of three distinct projects which have, I think, never been united before. These are: (1) The proposals for an organized migratory movement of population of Edward Gibbon Wakefield and of Professor Alfred Marshall; (2) the system of land tenure first proposed by Thos. Spence and afterwards (though with an important modification) by Mr. Herbert Spencer; and (3) the model city of James Silk Buckingham (101).

As far as the reference to Spence is concerned, Howard even quotes a famous passage from "a lecture read at the Philosophical Society in Newcastle, on 8th November 1775" he then goes on to examine the exact meaning of Spence's idea for his "Town-Country" idea, and in particular how the system for capturing the "development value" in his own scheme is related to Spence's Land Plan.

Spence's intellectual life, very much like Howard's, was dominated by one "big idea". For Dickinson the hierarchy of Spence's interests is very clear:

Thomas Spence was a prolific radial propagandist who produced a stream of pamphlets, broadsheets, poems, songs and periodicals during the age of the democratic revolution from 1775 to 1815 . These works consistently supported radical demands at home and the revolutionaries abroad, but their importance lies in Spence unique Land Plan which advocated the abolition of all private property and the creation of democratic, self-governing parochial communes (8).

The formulation by Spence of a Land Plan was more or less directly a consequence of the tense social climate in the North-East of England in general and in the Newcastle area in particular, but was also a response to events of national importance. As early as the 1770s, in the wake of the Wilkes affair, whose echoes had reached Newcastle, the town had a number of active radical societies. But it was the Newcastle Town Moor case 
which really planted the seed of the Land Plan in Spence's mind. In 1770 the Newcastle town Corporation had unilaterally decided to enclose part of the Town Moor, which freemen and tenants customarily used to graze their cattle, but was eventually constrained by a 1774 Act of Parliament (The Newcastle Town Moor Act) that limited the acreage of leasable land to a hundred acres-a small portion of the moor land-and subjected leasing to the freemen's approval. Before this happy conclusion-for the freemen-had been reached, a local judicial battle had seen Spence and his mentor James Murray, the minister of his Presbyterian congregation, engaging in propaganda in defence of the freemen's and tenant's interest in the matter. The leader of the Newcastle Constitution Club, founded in 1772, had hired the services of Serjeant-at-law John Glynn, the politician and lawyer who had defended Wilkes against Parliament, to defend the customary and charter rights of freeholders and tenants who used the moor.

Dickinson writes of "the exorbitant power and oppressive methods of the local elite" (Dickinson 1982, 6) as a factor in the surge of radicalism in and around Newcastle. The Town Moor affair is certainly a case in point, and it clearly illustrates the conflict-laden social relations and power struggles of the town, prominently featuring the mobilisation of local radicals in support of the users of common land. But for Spence this episode may have been even more significant and meaningful. The message of egalitarianism and activism conveyed by the sermons and writings of Murray probably interacted in Spence's mind with this local affair and its legal conclusion, which was that the collective users and owners of the land could by rights decide collectively how the land ought to be managed and disposed of. For Spence the whole of this episode would be greater than the sum of its elements, and in the year after the Newcastle Town Moor Act, he gave the first public expression of his Land Plan, at a meeting of the newly created Philosophical Society of his home town, when, on 8 November 1775, he delivered his famous lecture on "The Real Rights of Man".

For the first time he publicly condemned the principle of private property in land and land-owners themselves, and offered his solution to the problem of the abuses of power to which commoners were routinely subjected: after dispossessing the local landlords of their lands (Spence was never very clear as to how that might come about), every parish should own and manage the land within parish boundaries for the benefit of the local inhabitant each and all. The lecture caused a commotion within the debating society, whose members did not in general receive it very well. Spence immediately set about publishing it without the Philosophical Society's permission of course, and started spreading the word in the streets of Newcastle: the parish, not to the landlords, is the rightful owner of the land, and accordingly the parish should have power and control over it.

The original text, in content and tone, is clearly subversive, and it does not even seem exaggerated to call it outwardly revolutionary. Its line of reasoning is clever and interesting: it is an attempt at logically demonstrating the "natural right" of communities to collective property. Land property for all is presented in Spence's lecture as one of two elementary birth-rights of mankind, of all peoples inhabiting the earth-the other being liberty. Spence resorts to the "state of nature" or "original state" argument to demonstrate that "originally", all members of a community could and did enjoy "all the advantages from their natural and equal rights of property in land and liberty" (Spence 1775, 1). The coupling of the right of liberty to that of the property of 
land is a clever discursive device, or trick, to fend off criticism. Who would deny mankind's natural right of liberty?

If Spence, as a number of commentators have remarked, cannot be reasonably considered as a "proto-Marxist", then the phrase "collective ownership of the means of production" is not what he had in mind. But "collective ownership of the means of subsistence", though still redolent of another context and another epoch, might perhaps not sound too much out of place here:"

That property in land and liberty among men in a state of nature ought to be equal, few, one would be fain to hope, would be foolish enough to deny. Therefore, taking this to be granted, the country of any people, in a native state, is properly their common, in which each of them has an equal property, with free liberty to sustain himself and family with the animals, fruits and other products thereof. Thus such a people reap jointly the whole advantages of their country, or neighbourhood, without having their right in so doing called in question by any, not even by the most selfish and corrupt. For upon what must they live if not upon the productions of the country in which they reside? Surely, to deny them that right is in effect denying them a right to live. Well, methinks some are now ready to say, but is it lawful, reasonable and just, for this people to sell, or make a present even, of the whole of their country, or common, to whom they will, to be held by them and their heirs for ever? (Dickinson 18)

Is it "legal", or right according to natural law, Spence asks, for a community to alienate that common property of the land, which is one of their fundamental rights, to the benefit of others? If the descendants of such a community are made of the same stuff as their ancestors, and are supposed to find sustenance and shelter and the others of life's necessities on the land, the answer must be: no; they have the same needs and therefore the same rights:

To this I answer, if their posterity require no grosser materials to live and move upon than air, it would certainly be very ill-natured to dispute their right of parting, for what of their own, their posterity would never have occasion for; but if their posterity cannot live but as grossly as they do, the same gross materials must be left them to live upon. For the right to deprive anything of the means of living, supposes a right to deprive it of life; and this right ancestors are not supposed to have over their posterity.

As ancestors do not have the right of life and death over their descendants, they cannot rightly deprive the following generations of their means of subsistence. The logical conclusion, of course, is that collective ownership of the land by all members of the community, because it alone can guarantee an equal share of the means of subsistence for each and all, is the only relationship between the land and the people that accords with "natural law", and thus has to be cherished and preserved as such, from generation to generation:

Hence it is plain that the land or earth, in any country or neighbourhood, with everything in or on the same, or pertaining thereto, belongs at all times to the living inhabitants of the said country or neighbourhood in an equal manner. For, as I said before, there is no living but on land and its productions, consequently, what we cannot live without we have the same property in as our lives.

Spence then proceeds to establish the origins of the situation at his time: if men live in a civilized state, i.e. in society, "the inhabitants of a country" might be expected to enjoy their "natural rights and privileges"-a substitute phrase for the right to collective land ownership and liberty-, at least as much as "necessity" will allow. But, of course, this is not the case at the time Spence was writing; indeed there was nothing in the "landed 
system" as inequitably distributed as "property in land". That is the result of the greed and acquisitive propensity of a few dominant individuals and families:

If we look back to the origin of the present nations, we shall see that the land, with all its appurtenances, was claimed by a few, and divided among themselves, in as assured a manner as if they had manufactured it and it had been the work of their own hands; and by being unquestioned, or not called to an account for such usurpations and unjust claims, they fell into a habit of thinking, or, which is the same thing to the rest of mankind, of acting as if the earth was made for or by them, and did not scruple to call it their own property, which they might dispose of without regard to any other living creature in the universe. Accordingly they did so; and no man, more than any other creature, could claim a right to so much as a blade of grass, or a nut or an acorn, a fish or a fowl, or any natural production whatever, though to save his life, without the permission of the pretended proprietor; and not a foot of land, water, rock or heath but was claimed by one or other of those lords; so that all things, men as well as other creatures who lived, were obliged to owe their lives to some or other's property, consequently they like the creatures were claimed, and, certainly as properly as the wood herbs, etc., that were nourished by the soil. And so we find, that whether they lived, multiplied, worked or fought, it was all for their respective lords; and they, God bless them, most graciously accented of all as their due. For by granting the means of life, they granted the life itself; and of course, they thought they had a right to all the services and advantages that the life or death of the creatures they gave life to could yield. (Dickinson 19)

The biting irony of tone is a measure of how much consideration Spence had for the landed aristocracy or landlords in general. He then continues the genealogy of the propertied classes with more scathing remarks in the same vein, but with increased intensity and earnest. If the aggravated author's unforgiving contempt for the "pretended proprietors" can easily be read between the lines in the previous passage, it increase in the next, and the following lines now bear witness to the young Spence's anger and vindictiveness. That landlords are mockingly likened to "gods" is not enough; he also declares the original landowners "usurpers and tyrants", their successors selfish transgressors of the law of natural liberty and land property, and common mankind their victims. If the common people have a right to "liberty, air, or the light and heat of the sun", just as equally land property is their natural right. And it follows therefore that if they cannot enjoy or exercise their legitimate access to land property, they are being robbed of one of their fundamental natural rights:

Thus the title of gods seems suitable enough to such great beings; nor is it to be wondered at that no services could be thought too great by poor dependent needy wretches to such mightly and all-sufficient lords, in whom they seemed to live and move and have their being. Thus were the first landholders usurpers and tyrants; and all who have since possessed their lands, have done so by right of inheritance, purchase, etc., from them; and the present proprietors, like their predecessors, are proud to own it; and like them, too, they exclude all others from the least pretence to their respective properties. And any one of them still can, by laws of their own making, oblige every living creature to remove off his property (which, to the great distress of mankind, is too often put in execution); so of consequence were all the landholders to be of one mind, and determined to take their properties into their own hands, all the rest of mankind might go to heaven if they would, for there would be no place found for them here. (Dickinson 19) the people from the natural benefits of the earth's bounty. After making up the laws that justify their exclusive property, by placing themselves under the same law as the 
rest of the people-that is to say, that men should live from the fruit of their "business"the "land-makers", as Spence mockingly calls the land-owning class, justify their eviction of common people from their natural right by...the law of nature:

Thus men may not live in any part of this world, not even where they are born, but as strangers, and by the permission of the pretender to the property thereof; which permission is, for the most part, paid extravagantly for, though many people are so straitened to pay the present demands, that it is believed if they hold on, there will be few to grant the favour to. And those land-makers, as we shall call them, justify all this by the practice of other manufacturers, who take all they can get for the products of their hands; and because that everyone ought to live by his business as well as he can, and consequently so ought the land-makers. Now, having before supposed it both proved and allowed, that mankind have as equal and just a property in land as they have in liberty, air, or the light and heat of the sun, and having also considered upon what hard conditions they enjoy those common gifts of nature, it is plain they are far from reaping all the advantages from them which they may and ought to expect. (Dickinson 19)

Spence's argument is about to reach its pivotal point here: for Spence has, as we know, a Plan. The Land Plan can be found under numerous different literary forms in Spence's works: The Poor Man's Advocate proposes one version, A Supplement to the History of Robinson Crusoe another. Other variants can be found in The End of Oppression (1795), A Marine Republic, or A Description of Spensonia (1795), and The Constitution of a Perfect Commonwealth (1798), for example. But this-the next two paragraphs in original lecture, which was republished in 1793 as The Real Rights of Man-is how Spence first formulated his Land Plan in 1775, at the age of only 25:

Let it be supposed, then, that the whole people in some country, after much reasoning and deliberation, should conclude that every man has an equal property in the land in the neighbourhood where he resides. They therefore resolve that if they live in society together, it shall only be with a view that everyone may reap all the benefits from their natural rights and privileges possible.

Therefore a day is appointed on which the inhabitants of each parish meet, in their respective parishes, to take their long-lost rights into possession, and to form themselves into corporations. So then each parish becomes a corporation, and all men who are inhabitants become members or burghers. The land, with all that appertains to it, is in every parish made the property of the corporation or parish, with as ample power to let, repair, or alter all or any part thereof as a lord of the manor enjoys over his lands, houses, etc,; but the power of alienating the least morsel, in any manner, from the parish either at this or any time hereafter is denied. For it is solemnly agreed to, by the whole nation, that a parish that shall either sell or give away any part of its landed property, shall be looked upon with as much horror and detestation, and used by them as if they had sold all their children to be slaves, or massacred them with their own hands. Thus are there no more nor other lands in the whole country than the parishes; and each of them is sovereign lord of its own territories. (Dickinson 19).

This then is the first part of Spence's Land Plan: the constitution of parishes into democratic corporations, of which "all men who are inhabitants" are citizens ${ }^{10}$, and the institution of the parish as collective landlord.

And this then, is exactly what Howard carefully chose to omit in his quotation-the root of the matter, the repossession by commoners of their natural right to property in land-, and selected the next one instead. Howard thus decided to quote Spence, but without mentioning the all-important context in which the extract takes it original and intended meaning. The revolutionary intention-the collective repossession and 
ownership of the land-is gone. Absent too, the scathing tone and bitter irony against the rapaciousness of landowners of the first part of The Real Rights of Man. What remains is the illustration of the financial power of the parish corporation as land-owner, and the explanation of the advantages of such a system for the denizens of the parish in term of taxation.

51 Indeed, after asserting "the necessity of first buying the land, so that the most admirable project of Thomas Spence can be put into practice", Howard quotes from the original text... or so it might seem to an uninformed reader. In fact, Howard produces a specially formatted passage, made up of two different parts extracted from the original, combined to suit his purpose. His intention, in the following excerpt, is to demonstrate that the rent paid by the inhabitants to the corporation gives that local government body the financial ease and independence of which its subordination to central government had previously deprived it:

Spence's proposal, put forward more than a hundred years ago, at once suggests how to secure the desired end. Here it is:

'Then you may behold the rent which the people have paid into the parish treasuries, employed by each parish in paying the Government its share of the sum which the Parliament or National Congress at any time grants; in maintaining and relieving its own poor, and people out of work; in paying the necessary officers their salaries; in building, repairing, and adorning its houses, bridges, and other structures; in making and maintaining convenient and delightful streets, highways, and passages both for foot and carriages; in making and maintaining canals and other conveniences for trade and navigation; in planting and taking in waste grounds; in providing and keeping up a magazine of ammunition, and all sorts of arms sufficient for all its inhabitants in case of danger from enemies; in premiums for the encouragement of agriculture, or anything else thought worthy of encouragement; and, in a word, in doing whatever the people think proper; and not, as formerly, to support and spread luxury, pride, and all manner of vice.... There are no tolls or taxes of any kind paid among them by native or foreigner, but the aforesaid rent which every person pays to the parish, according to the quantity, quality, and conveniences of the land, housing, etc., which he occupies in it. The government, poor, roads, etc. etc., as said before, are all maintained by the parishes with the rent; on which account all wares, manufactures, allowable trade employments or actions are entirely duty free.' (103)

One might think that once Howard starts citing from the text he would quote the original text. Yet the above passage is the result of some careful and clever editing on Howard's part: he first truncated the paragraph from which he excerpted the first part of this quote (from the beginning down to "all manner of vice...." -sic: four dots), leaving only about the first half of the original paragraph, and then added the second part, also a fragment from another paragraph found in Spence's text seven paragraphs further down. The missing end of the first paragraph cited by Howard reads as follows:

As for corruption in elections, it has now no being or effect among them; all affairs to be determined by voting, either in a full meeting of a parish, its committees, or in the house of representatives, are done by balloting, so that votings or elections among them occasion no animosities, for none need to let another know for which side he votes; all that can be done, therefore, in order to gain a majority of votes for anything, is to make it appear in the best light possibly by speaking or writing. Among them Government does not meddle in every trifle; but on the contrary, allows each parish the power of putting the laws in force in all cases, and does not interfere but when they act manifestly to the prejudice of society and the rights and liberties of mankind, as established in their glorious constitution and laws. For the judgment of a parish may be as much depended upon as that of a House of 
Lords, because they have as little to fear from speaking or voting according to truth as they. (Dickinson 20) peers, or friends and supporters of members of the House of Lords, and might at any rate be rich, powerful or influential people who could perhaps be of assistance in putting his plan into practice. In fact Howard did turn to great landowners such as Lord Salisbury or Lord Desborough, for political and financial support or when looking to buy land for the implementation of his project. But it was not the end of the above paragraph that must have caused Howard to exclude it from his quotation of Spence. The beginning of that fragment is what jars with the very quiddity of the Garden City: elections by secret ballot, a house of representatives, etc., all point to a democratic system. And that is precisely what the Garden City governance is not. Howard writes in an endnote of the first chapter (18) that he uses the word "municipality" in a loose analogical sense only, not in its usual political acceptation: "This word, 'municipality', is not used in a technical sense".

Certainly it would not matter too much if Howard had edited the original on grounds of clarification of Spence's idea or language. But what is remarkable here for anyone who is able to compare Howard's quote with the original, is that the missing half of the first paragraph in the first part of Howard's "quote" actually contradicts one of the essential features of his scheme: the Garden City is not the result of a public endeavour, and is governed not by a publicly elected council but by a private company; the so-called "municipality" which governs the Garden City it is fact not a democratic public institution, nor does it purport to be. It is subordinate to a company board looking for dividends for its investors. Most of all, it is not created by all its inhabitants to reestablish the "long-lost rights" of the dispossessed, like Spence's parish corporation. The Garden City scheme was formulated to try and achieve a new form of human settlement that would found a new harmony between the rural and the urban on the collaboration of all individuals of all classes. Through its spatial planning and, above all, through its social organisation, it would solve or preclude the problems of both the urban and the rural environments of the time.

It is useful to remember here that the spatial provisions of the Garden City project, though there are the best known aspect of Howard's idea, are in fact secondary. The spatial planning aspect is a means to an end-the reconciliation of Town and Countryand not deeply original. What really characterizes the Garden City programme as a unique proposal is its organizational structure. As such it is obvious at this stage that it is not compatible with either Spence's general goal of repossessing the dispossessed, or his particular objectives of setting up a free democratic land-owning commune to empower them politically.

Howard's editing did not stop at the operation we described above, however. The second fragment of his quotation is also incomplete, and Spence's original, after "duty free", actually reads:

Freedom to do anything whatever cannot there be bought; a thing is either entirely prohibited, as theft or murder; or entirely free to everyone without tax or price, and the rents are still not so high, notwithstanding all that is done with them, as they were formerly for only the maintenance of a few haughty, unthankful landlords. For the government, which may be said to be the greatest mouth, having neither excisemen, customhouse men, collectors, army, pensioners, bribery, nor such like ruination vermin to maintain, is soon satisfied, and moreover there are no 
more persons employed in offices, either about the government or parishes, than are absolutely necessary; and their salaries are but just sufficient to maintain them suitably to their offices. And, as to the other charges, they are but trifles, and might be increased or diminished at pleasure.

The same remarks as for Howard's verbal prudence à propos landowning interests (in the first abridged paragraph) apply here, but this time with regard to modes of government. Essentially it is the system of local government imagined by Spence, and its relationship with central government that Howard does not wish to mention in his own text. Howard-supposedly a great admirer of Kropotkin the anarcho-communisthas no use for Spence's self-sufficient parish or his overt critique of the parasitic nature of central government.

Another point can be made about the marked difference between Spence's social message and Howard's. Whilst the latter envisages setting up a new community by "first buying the land" and then trying to pay off the debt that is the birth-mark of Garden City, through complex financial arrangements ${ }^{11}$, the former considered simply that it was the landlords who were indebted to the people-not the other way round. Spence thought the landlords have long been indebted to the common people, whereas Howard inaugurates his "Town-Country" settlement by burdening it with an original debt.

It is plain to see that the collage Howard obtained with the juxtaposition fragments, after tinkering so liberally with the original, is exactly suited to his intention, of course: what Howard wanted to insist on was the self-financing model of which Spence had given an intimation in a very different context, with very different intentions. Spence is clearly the inventor of what Howard eventually called his "rent-rate" system. But in trying to adapt this idea into his Garden City plan, Howard betrayed the original intention of the Jacobin revolutionary radical.

Whereas Spence imagined that the idea of dispossessing all landowners, if and when it began to be adopted, could propagate itself throughout the land because it provided the best answer to the problems of the labouring poor, Howard meant to integrate this system of rate-rents to turn the first Garden City into a "brilliant marketing device" (Hall and Ward 1998, 26). Howard counted on the success of the first of this kind of settlements to contaminate more landowners and investors, who would then replicate the initial model. "As Howard saw it, the first Garden City would act as shining exercise in public relations", according to Hall and Ward (Hall and Ward 1998, 26). Howard wanted to attract capitalists because his scheme could not work without them. It was them who could in turn be the real overlords of the Garden City inhabitants, through the limited-dividend company which was concerned only by the return on the invested capital. The references to "co-operation" and "mutual aid", however well-intentioned, cannot hide the true nature of his project, which is to unleash the potential of capital investment in an undeveloped area.

61 Of course Howard's prose could not very well include the passages which he deliberately excised. But the fact remains that his use of Spence's parish rent totally betrays the original, in letter and spirit both. But what Howard kept in this editing exercise is just as precious as what he left out for an understanding of his use of Spence. What he extracted, kept and recycled from The Real Rights of Man is the idea that the local community institutions fund themselves from the land-rent that local residents pay according to the quantity and quality of land at their disposal, and in particular 
(but not to the exclusion of others occupations) that farmers and agree to pay for the use of farming land. This idea Howard transformed into his "rate-rent" concept, whereby the rent payable by inhabitants and private companies contains the monies for the repayment of the initial debt (interest and principal being two separate items in Howard's plan), the local rate and finally, after repayment of the debt, "welfare" services for the population.

It is highly probably that Howard, in this last respect too, is heavily indebted to Spence, who had himself developed a vision of a service-providing parish, again based on the financial capacity of the population's rent. Even if the term "welfare state" is perhaps overly anachronistic, but Dickinson's observation clearly illustrates how much Howard most probably borrowed from Spence, but did not acknowledge:

At various times Spence advocated that the parochial corporations should provide public housing, public assembly rooms, public schools, public libraries, public hospitals, public theatres, public granaries, public swimming facilities and public relief for the aged, the sick, the orphaned and the unemployed. His vision of a welfare state was more extensive even than that outlined by Thomas Paine in the celebrated second volume of Rights of Man. ${ }^{12}$

All in all, Howard's indebtedness to Spence is possibly very extensive, and stretches far beyond the idea of a simple financing device for a locality. Indeed, Howard is likely to have found inspiration in Spence's Land Plan for three main structural elements of his Garden City concept: the first is the notion of local scale change in matters of ownership, governance and administration; second, the idea of the "rent-rate", the very source of the financial independence and self-determination of the local community; and thirdly, Howard's project of the (market) contagion of change is redolent of Spence's vision of the country's parishes all turning into democratic corporations. Considered together, these elements cover so much of the Garden City project's foundations that they leave little doubt about the centrality of Spence's Land Plan as an inspiration for Howard.

Moreover, in all these respects, and as far as Spence is concerned, Howard can only be said to have betrayed the original destination of the ideas he drew inspiration from, and, with them, their author, because he did not specify their initial function and usage. However, Howard did "invent", or at least put together from variegated sources, a concept which, in theory at least, appeared to have all the makings of a practicable plan. Experience eventually proved otherwise, but at least Howard got to put his ideas to the test of reality. That much cannot be said of Spence, of course. This is hardly surprising: the comparison and contrast between Howard the capital-compatible reformist and Spence the revolutionary agitator show how radical and total the latter's demands for change were, when the former wanted to change the form of society without changing its content. The higher authorities of their respective times perhaps adequately valued the inherent value, power and danger of each thinker's ideas, when they repeatedly sentenced Spence to imprisonment on the one hand, and, on the other, shrugged indifferently at Howard's unique proposal.

Howard's attitude raises yet more questions about his intentions and his method. Why did he make use of Spence's Land Plan, a source not completely unknown in the radical circles of his time, only to simplify it, distort it and betray it? Why did he run the obvious risk of being found out tampering with historical and textual accuracy, and in doing so, of discrediting his grand idea, let alone his own reputation? Did Howard draw inspiration from some of the interpretations of Spence that were more or less common 
at the turn of the $19^{\text {th }}$ century? These questions might never be answered with a reasonable degree of certainty, firstly because the reception of Spence's ideas outside the group of his faithful followers is not well enough documented, and knowledge about that reception and its evolution is only fragmentary. Also, Howard himself never took the trouble to explain in detail the use he made of his sources. We can understand why he was so discreet as we consider the distortions he inflicted on Spence's original idea.

There are a few known elements, however, that might shed some light on these questions. First, the different contexts might go some way towards explaining Howard's "simplified" use of Spence's Land Plan idea. Spence was trying to appeal to like-minded radicals and perhaps to win over the more pigeon-livered reformists among his contemporaries by convincing them that nothing short of dispossessing the landlords could bring about and guarantee the continuation of a fair society. Howard, on the other hand, apart from the rather tactical choice of references in his book-shedding the more revolutionary and anti-landlord aspects of the Land Plan in order to try and attract the cooperation of landowners and investors-generally formed his plan in an ideological environment that was very likely to lead him to reinterpret Spence's ideas in an altogether more benign way. The teachings and preachings of the likes of the Zetetical society, the various spiritualist chapels, along with Kropotkin's anarchocommunism itself were all processed in the quest for the ideal formula of a wellbalanced human settlement. Through this kaleidoscopic intellectual spyglass, the message of the Fellowship of the New Life, as well as that of its political offshoot, the Fabian Society, Bellamy's sanitised utopia and Kropotkin's mutualism, Buckingham's model city, and many other influences were reconfigured to suit Howard's own mild reformist temperament.

67 And the aspects which interested Howard the most were clearly not the revolutionary ones but the "communitarian", consensual and locality-centred functions of the industrial villages from Kropotkin's Fields, Factories and Workshops, or Mutual Aid: A Factor of Evolution or even The Conquest of Bread. Howard's mental universe was one wholly oriented towards the appeasement of social relationships and away from conflicts as the resolution of social tensions. In this respect Howard was perhaps a typical product of his time. His education, environment, and experience placed him at the centre of gravity of the reformist movement of his period, of which the Fabian society, with its political gradualism, is another exemplar.

The difference between Spence's vehement class vindictiveness and Howard's mild and consensualist utopianism can also, perhaps, be illustrated by the broad evolution of political radicalism as a movement and thought between Spence's time and Howard's. The prevalent mood in radical circles towards the end of the $18^{\text {th }}$ century and the first half of the $19^{\text {th }}$ century seems to have been one of outrage and sometimes rebellion against the established order or system-the "Thing" as Cobbett called it. The chartist movement in turn, in spite of the violent strand manifest in some of its activists, mainly sought to integrate the working classes into the system itself, and devoted more energy to its claims of political representation than it did challenging socio-economic inequalities. This, broadly speaking, would be its political legacy to the British workingclass movement, which after the "revival" of the 1880, would mainly seek the advancement of the labouring classes' interests through parliamentary representation. Howard's own attitude of "peaceful reform" reflects the general disposition of the 
majority of those who, although involved in the tense confrontations and intense conflicts of the period, had essentially abandoned the bitter and sometimes subversive radicalism of their precursors.

Secondly, there seems to have been only one explicit reference to and apparent endorsement of Spence's Land Plan in existence at the time Howard wrote Garden Cities of To-morrow, and it was that of the British socialists-of some of the British socialists, more accurately. The socialist-inspired Land Nationalisation Society, formed in 1881, promoted the eponymous idea under various guises, from compulsory purchase to progressive nationalisation of all land for all the community, but if the link to Spence is not improbable it is as yet undocumented (the moving spirit of the Society, the scientist Alfred Russel Wallace, did not once refer to Spence in his Land Nationalisation, its Necessity and its Aims from 1882). It is H.M. Hyndman, the founder of the Social Democratic Federation (in 1881) who seems to have reintroduced Spence's ideas into the intellectual land-reform sphere of the period. In his book The Nationalisation of the Land in 1775 and 1882, Spence's pamphlet was reproduced as The Rights of Man, as Exhibited in a Lecture, Read at the Philosophical Society in Newcastle, in November 1775.

This is likely to be where Howard found some of his inspiration and one of his three key "proposals" when he discovered Spence's Plan. Engels saluted the resurrection or rather the exhumation of "good old Spence", and the use of his name for the good of the socialist cause. Spence was, after all, a socialist radical of sorts, as well as a defender of the common man, and it could not hurt to claim some form or degree of affiliation. But Hyndman's Spence on that occasion looked rather more embalmed than resuscitated: overall land nationalisation by central government was never the guiding principle of his plan for the popular appropriation of aristocratic land, which was based on the municipalisation of land in some parishes first, and then, by contagion, to other parishes, hopefully spreading on the scale of the whole nation. But for the British socialist of the end of the $19^{\text {th }}$ century, Spence's name was a useful token of radicalism, a prestigious reference as a popular rebel, more than a source of any real measure of doctrine. He was never again, after that mention, a central character in the legend of the fore-runners and pioneers of British socialism. Most commentators usually belittle his contribution to socialism and consider him an isolated crank, even when they recognise his importance as a leader and an inspiration for fellow-spirits. Others, however, have recently "rediscovered" the value of Spence's ideas and his commitment to social change for the benefit of common people. But that, of course is another story. 13

71 Howard, as we have seen, was no admirer of socialism, British or otherwise. It is doubtful he drew much inspiration from Hyndman's erroneous and pragmatic (or opportunistic) "interpretation". But he found Spence and his Plan there. For example, this idea of the replication of the local process of change was adopted and adapted by Howard who dreamed of a country won over by Garden Cities and Social Cities. Typically, he most probably did so without anyone's help. George Bernard Shaw famously wrote of Howard that he was one of those "heroic simpletons" who achieve great things while the great and the good look down with contempt or pity on the "impossible" and "utopian" achievements.

72 In the same way that he usually gets credit for his famous "unique combination of proposals", there seems to be no good reason to argue that, for all of the extraneous influences and references, Ebenezer Howard should not be judged entirely responsible 
for his audacious and indelicate treatment of Spence's original ideas. The history of ideas often marches forward in such false steps and bold leaps, and it is perhaps a fitting ruse of history that, a century later, Howard is sometimes called such names as "radical socialist.". ${ }^{14}$ Probably by people who have never heard of Spence, who was perhaps another of history's decried "simpletons", but one who more truly deserves such a description.

\section{BIBLIOGRAPHY}

Armstrong, Keith and Bonnett, Alastair (eds). Thomas Spence: The Poor Man's Revolutionary. London: Breviary Stuff Publications, 2014.

Bonnett, Alastair. Left in the Past: Radicalism and the Politics of Nostalgia. London: Bloomsbury Publishing, 2010.

Brunetta, Grazia and Moroni, Stefano. Contractual Communities in the Self-Organising City:Freedom, Creativity, Subsidiarity. London: Springer, 2012.

Buckingham, J. Silk. National Evils and Practical Remedies. 1849. Clifton: Augustus M. Kelley, 1973.

Dickinson, H. Thomas (ed.). The Political Works of Thomas Spence. Newcastle upon Tyne: Avero, 1982.

Foldvary, Fred. Public Goods and Private Communities: The Market Provision of Social Services. Aldershot: Edward Elgar, 1994.

Gallop, G. I. (ed.). Pig's Meat. London: Spokesman: 1982.

Hall, Peter and Ward, Colin. Sociable Cities: The Legacy of Ebenezer Howard. Chichester: Wiley, 1998.

Heath, Spencer. Citadel, Market and Altar. Baltimore: The Science and Society Foundation, 1957.

Howard, Ebenezer. Garden Cities of To-morrow. 1902. London: Faber \& Faber, 1946. (original title: To-morrow! A Peaceful Path to Real Reform.: London, 1898.)

Sadoux, Stéphane, F. Cantaroglou and A. Gloor. "The Governance of New Communities in Britain, France and North America, 1815-2004: The Quest for the Public Interest?" In Body-Gendrot, Sophie, J. Carré and R. Garbaye (eds). A City of One's Own. Blurring the Boundaries Between Private and Public. Aldershot: Ashgate, 2008.

Stigler, George. "Ricardo and the 93\% Labor Theory of Value". The American Economic Review vol. 48: No. 3 (Jun., 1958): 357-367.

Thompson, E. P. The Making of the English Working Class. 1963. London: Penguin Books, 1991.

Ward, S.V. (ed.). The Garden City: Past, Present and Future. London: Spon, 1992. 


\section{NOTES}

1. The original title for the 1898 edition was Tomorrow! A Peaceful Path to Real Reform. Howard then changed this to Garden Cities of To-morrow, in the 1902 and subsequent editions, under which title it gained a certain notoriety.

2. The reference is to the text of Spence's first expression of his "Land Plan", in a lecture he gave at the Newcastle Philosophical Society in 1775. This was later published as The Real Rights of Man (1793). For the numerous other versions of the Plan, see Dickinson (1982, preface).

3. See for example Dickinson (1982), preface.

4. See the introduction in Gallop (1982).

5. Howard had first thought of other expressive names like "Unionville" and "Rurisville" for his project, but later opted for the already existing "Garden City".

6. See for example Hall and Ward (1998, 3-27).

7. From Howard, 1898, chapter 6 ("Administration")

8. The reference is to the first public expression by Spence of his idea of a free democratic landowning parish. The Newcastle Philosophical Society, a local debating society which sometimes examined political ideas, was founded in 1775 . Spence immediately became a member and soon caused a scandal with this lecture in which he very virulently castigated the land-owning classes and offered his solution of local collective ownership by the parish corporation to replace the private property of land.

9. I have reproduced the whole of Spence's pamphlet in the quotations hereafter. It is only a short text, and even if some of the quotes might appear lengthy in the present context, it is part of the argument of this article that Howard's editing of The Real Rights of Man is both the consequence of his personal handling of the original, and the potential cause of a serious misunderstanding about Spence's own ideas. I wanted to avoid the possibility of, at least, the very same criticism for an article critiquing Howard's attitude.

10. That Spence expressed elsewhere his intention of giving women the same rights as men, except in legislative representation, is somewhat reassuring, but that intention does not appear as such in The Real Rights of Man.

11. As illustrated in Howard's diagram "The Vanishing Point of Land-Lord's Rent" ; see for example Hall and Ward $(1998,27)$.

12. Dickinson, 1982, 10.

13. This story is told partly in, among others, Alastair and Armstrong (eds). Thomas Spence: The Poor Man's Revolutionary. London: Breviary Stuff Publications, 2014; and Bonnett. Left in the Past: Radicalism and the Politics of Nostalgia. London: Bloomsbury Publishing, 2010.

14. For example Oliver Wainright, in "The garden city movement; from Ebenezer to Ebbsfleet", Monday 17 March 2014, The Guardian online. http://www.theguardian.com/artanddesign/ architecture-design-blog/2014/mar/17/ebbsfleet-garden-city-george-osborne

\section{ABSTRACTS}

Ebenezer Howard, the father of the "Garden City" idea, explains in one of the concluding chapters of his Garden Cities of To-morrow (1898) that his concept is only the combination of three pre-existing ideas in the area of land and urban reform. One of these sources is the famous "Land Plan" of the revolutionary radical Thomas Spence (1750-1814). After characterising the social and 
political meaning of Spence's "plan" and examining the content of the "unique combination of proposals" that is the Garden City in theory, the article seeks to explore how Howard's borrowing from Spence takes part in an attempt to answer the so-called "land question" that runs through the $18^{\text {th }}$ and $19^{\text {th }}$ centuries. Howard's project is rather socially conservative and based on class collaboration, inter-individual co-operation and mutual aid, all within an appeased version of capitalism (the original title of his book was To-morrow! A Peaceful Path to Real Reform until 1902). As such, it seems difficult to reconcile with Spence's revolutionary ideas, which include the dispossession of land-owners as well as the ownership and control of all parish land by democratic parish corporations. A careful reading of both sources, as well as a close examination of the handling of Spence's text by Howard, reveal that, in order to import certain aspects of the Land Plan into his own concept, the latter took with the former's ideas liberties that verge on intellectual betrayal.

Ebenezer Howard, le père de l'idée de "cité-jardin ", explique à la fin de son ouvrage Les citésjardins de demain (Garden Cities of To-morrow 1898) que son concept n'est rien d'autre que la combinaison de trois idées préexistantes dans le domaine de la réforme agraire et urbaine. L'une de ces sources est le «plan foncier» («Land Plan») du radical révolutionnaire Thomas Spence (1750-1814). Après avoir caractérisé le sens social et politique du " plan » de Spence, et examiné le contenu de la « combinaison unique de propositions » qu'est en théorie la cité-jardin, le présent article s'attache à examiner comment l'emprunt de Howard à Spence s'inscrit dans un projet de réponse à la «question foncière " qui traverse les $18^{\mathrm{e}}$ et $19^{\mathrm{e}}$ siècles. La tentative de Howard est plutôt socialement conservatrice et fondée sur la collaboration des classes, la coopération interindividuelle et le mutualisme, dans le cadre d'un capitalisme apaisé (le titre original de son ouvrage était Demain! Une voie paisible vers la réforme jusqu'en 1902). Elle semble difficilement conciliable avec les idées révolutionnaires de Spence, dont le plan foncier se fondait sur l'expropriation des grands propriétaires terriens et l'appropriation des terres par des municipalités démocratiques fondées sur les paroisses. Une lecture attentive des deux textes, et un examen rapproché de l'usage de celui de Spence par Howard, montre qu'afin d'intégrer certains aspects du plan foncier dans son montage conceptuel, le second a pris avec la pensée du premier certaines libertés qui ressemblent à de la trahison intellectuelle.

\section{INDEX}

Keywords: central government, collective ownership, commune, contractual communities, garden city, history of ideas, land nationalisation, "land plan", land reform, local democracy, local rates, municipal corporations, parishes, parish corporations, private property, revolutionary radicalism, rent, "rate-rent"

Mots-clés: cité-jardin, communautés contractuelles, commune, démocratie locale, gouvernement central, histoire des idées, loyer, impôt local, « impôt-loyer », municipalité, nationalisation foncière, paroisse, « plan foncier », propriété collective, propriété privée, réforme foncière, radical, révolutionnaire

\section{AUTHORS}

\section{JEAN-YVES TIZOT}

Maître de conférences

Université Stendhal - Grenoble 3

jean-yves.tizot@u-grenoble3.fr 